\title{
Habitat Preferences of Juvenile Abalone (Haliotis mariae Wood, 1828) Along the Dhofar Coast of Oman and Implications for Conservation
}

\author{
Schalk Willem Petrus de Waal ${ }^{*}$, Mohammed Balkhair, \\ Ali Al-Mashikhi, and Salem Khoom
}

Fisheries Research Centre-Salalah, Ministry of Agriculture and Fisheries Wealth, P.O. Box 33, Salalah, P.C. 217, Sultanate of Oman

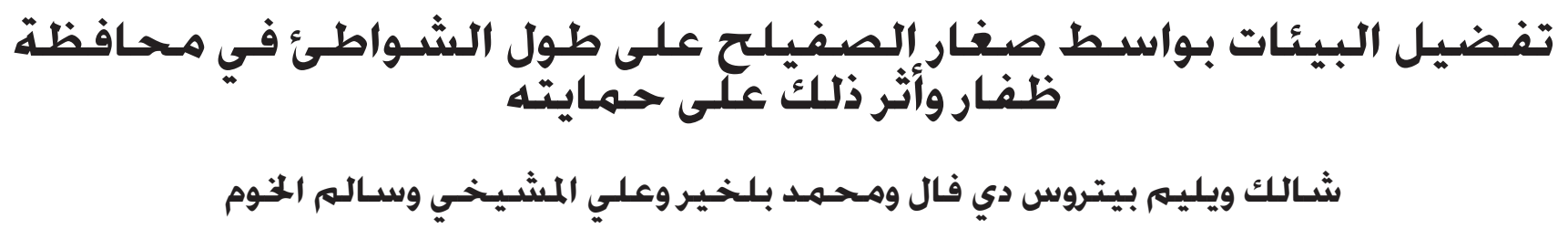

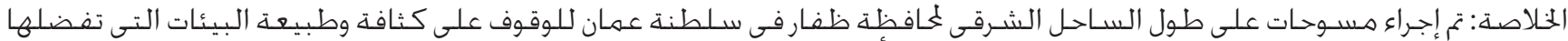

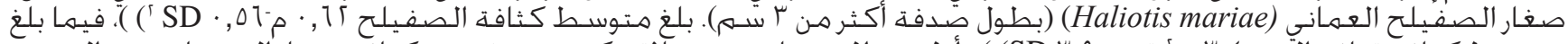

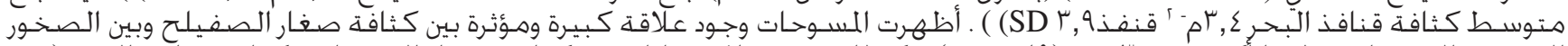

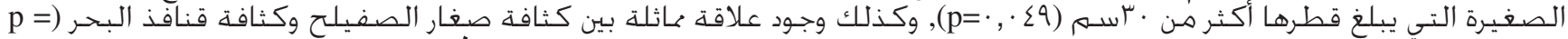

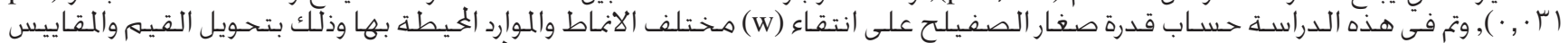

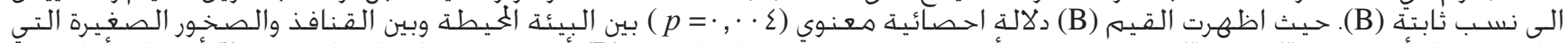

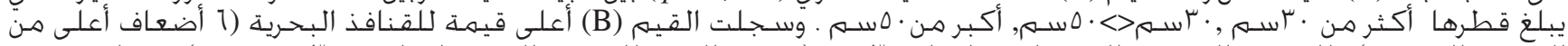

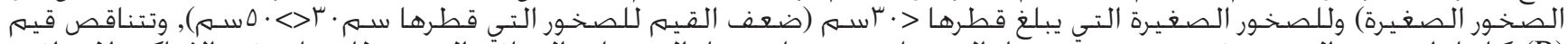

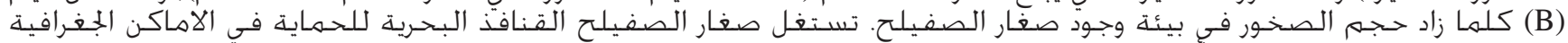

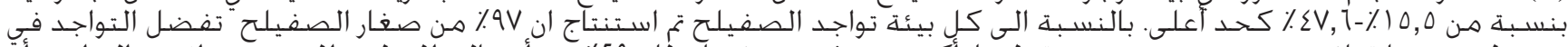

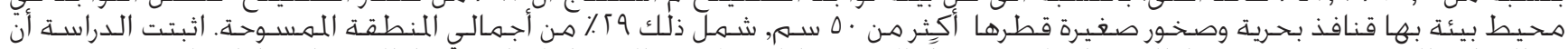

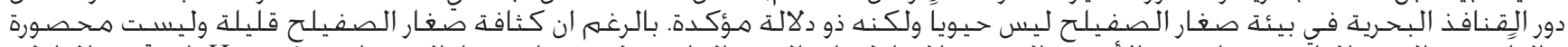

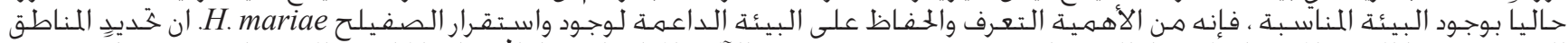

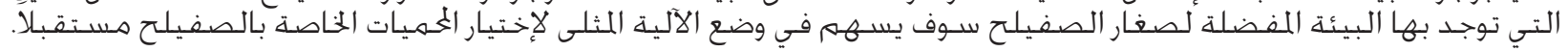

$$
\text { كلمات مفتاحية: صفار الصفيلح ، تفضيل البيئات، ختاليل الإختيار ، حماية الموطن ، عمـان. }
$$

ABSTRACT: Surveys were conducted along the eastern Dhofar coast of Oman to investigate densities and habitat preferences of juvenile Haliotis mariae ( $<3 \mathrm{~cm} \mathrm{SL}$ ). Average density was $0.62 \mathrm{~m}^{-2}$ (SD 0.56); average urchin density was 3.4 urchins $\mathrm{m}^{-2}$ (SD 3.9). Relationships between juvenile abalone densities and small boulders $(<30 \mathrm{~cm}$ in diameter $(\varnothing))$ tested significant $(p=0.049)$, as did those between juvenile abalone and urchin densities $(p=0.031)$. Selectivity $(w)$ and standardized (B) ratios quantifying the relative probability of selection by juvenile abalone for different categories of resource available were calculated. For the studied area $\mathrm{B}$ values tested significantly different for ( $p=0.004)$ the different habitats, urchins, boulders $<30 \mathrm{~cm}, 30><50 \mathrm{~cm}$, and $>50 \mathrm{~cm} \emptyset$, respectively. B values were highest for urchins $(6$ times that for small boulders), and for boulders $<30 \mathrm{~cm} \emptyset$ (double that for boulders $30><50 \mathrm{~cm} \varnothing$ ). B values for boulder habitats decreased as boulder size increased. Urchin utilisation by juvenile abalone as shelter ranged between geographic areas from a minimum of $15.5 \%$ to a maximum of $47.6 \%$. The proportion of total habitat that is preferred by more than $97 \%$ of juvenile abalone found, including urchins and boulders $<50 \mathrm{~cm} \emptyset$, comprises $29 \%$ of surveyed substratum. While the role urchins play on wild juvenile H. mariae has not proved vital, it is definitely significant. Although juvenile densities are low and are not currently limited by the availability of suitable habitat, it is crucial to identify and conserve those microhabitats that support recruitment of $H$. mariae. The abundance of these areas should be among the criteria used in selecting protected conservation areas.

Keywords: Juvenile abalone, habitat preferences, selectivity analyses, habitat conservation, Oman.

\section{Introduction}

The wild abalone fishery along the eastern Dhofar coast of Oman has formed part of traditional fishing culture for decades, and as a valuable commercial species contributes substantially to the livelihoods of coastal dwelling fisher folk (Al Hafidh, 2006). The fishery takes place in the winter months, usually between October and December, when the seas are relatively calm and sea water temperatures are in excess of $20^{\circ} \mathrm{C}$ (Al Hafidh, 2006; Sanders, 1982).

Haliotis mariae is the only abalone species occurring in Oman. It is endemic in the Dhofar region of the Arabian Sea (Al Hafidh, 2006). Currently, it inhabits a rocky coastal 


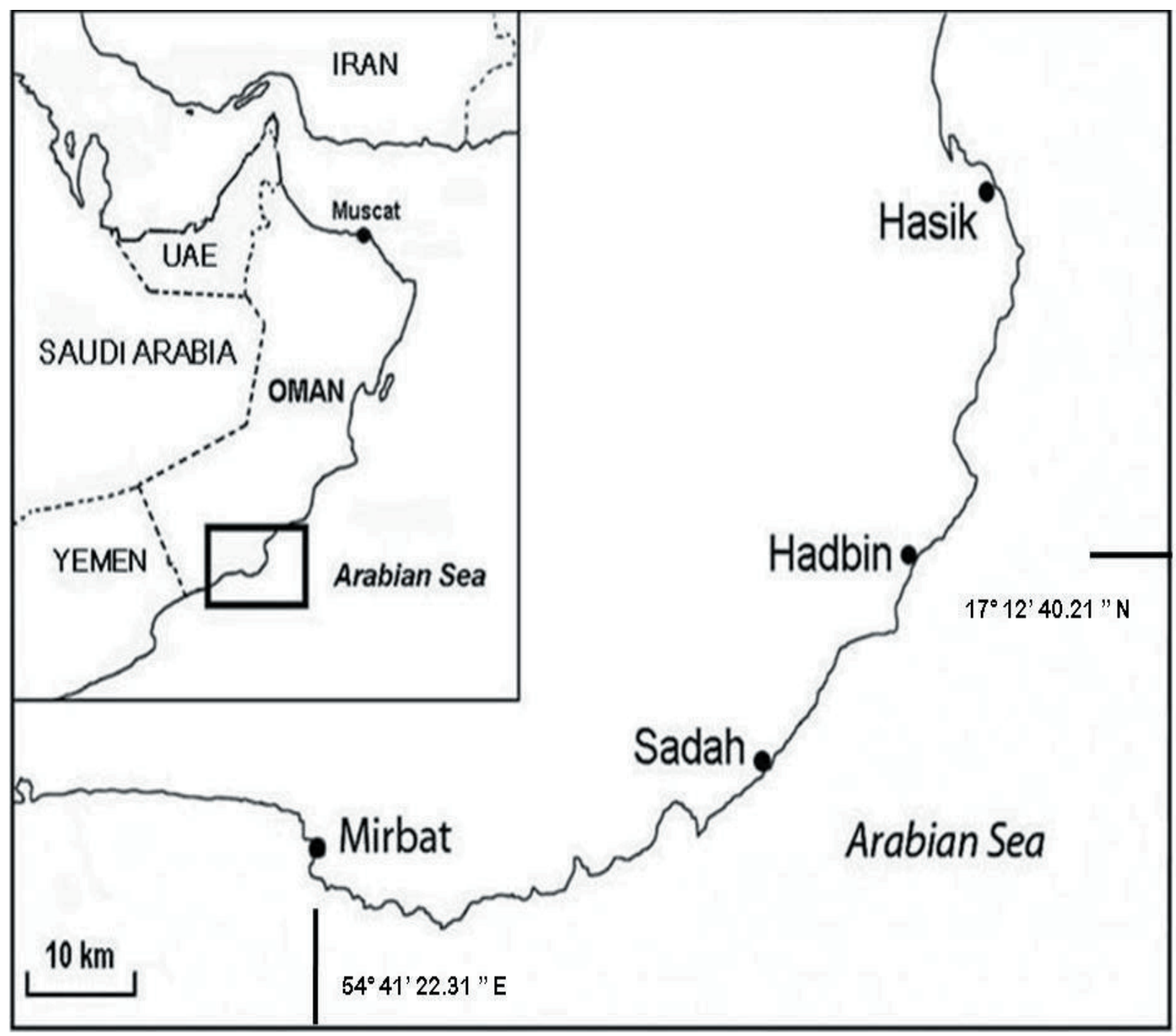

Figure 1. The main centres for the existing abalone fishery along the Dhofar coast of Oman.

zone between Mirbat and Hassik, approximately 100 $\mathrm{km}$ in length (Fig. 1). Prior to 2008 the species range extended approximately $80 \mathrm{~km}$ further east from Hassik to Ras Sharbithat (Al-Hafidh, 2006). However, an extreme episode of harmful toxic algal blooming by the species Cochlodinium polykrikoides during 2008 and 2009 (Al Gheilani, 2009) wiped out virtually all the abalone in the Ras Sharbithat region. As a result of the commercial importance of the species, worth approximately OR 8.2 million in 2012 (Fishery Statistics, 2012), extra consideration is being given to the management of the fishery.

The annual abalone survey now includes juvenile specific surveys to broaden the investigation into the dynamics of the species. The lifecycle of abalone in general can be considered complex. Juvenile abalone are sensitive to bright light (Heasman et al., 2007) and as a result cryptic by nature. They generally inhabit under-boulder habitats, cracks and crevices (Roberts et al., 2007; Dixon et al., 2006), becoming emergent as they mature. Abalone, specifically juveniles have a wide range of predators from which they need to seek refuge. These include sea stars, moray eels, lobsters, crabs, some species of fish, and octopus. Many of these predators inhabit the same general habitat, under-boulder, cracks and crevices, as the abalone themselves, making it crucial for juvenile abalone to find suitable shelter. In this study, we have investigated juvenile abalone up to $30 \mathrm{~mm}$ in SL (shell length), i.e. the cryptic juvenile phase. These animals differ in diet and behavior from adult animals. $H$. mariae is considered generally to become emergent at approximately $60-\mathrm{mm}$ SL moving onto exposed sites on reefs or boulders. Adult $H$. mariae are grazers as well as trappers of a range of drift seaweed species, with the choice of species depending on the area and the abundance and diversity of seaweeds present (Al-Hafidh, 2006). Juveniles, on the other hand, have been shown to be grazers, the epithelial layer of the encrusting corallines 
on which the recruits are found, together with benthic diatoms, are a source of nutrition for recruits and small juveniles (Al-Rashdi and Iwao, 2008). The association between urchins and abalone is well documented for various abalone species worldwide. However, this association is not always simple, in some cases urchin and abalone numbers are inversely related due to their competition for food (Tarr et al., 1996; Andrew and Underwood, 1992). Recruits from some species that grow to the juvenile stage have been found predominantly under sea urchins (Goodsell et al., 2006, de Waal, 2005, Day and Branch, 2002, 2000). Although urchins are considered a source of shelter for juvenile abalone the relationship between $H$. mariae recruits and urchins has not yet been investigated (Al-Hafidh, 2006). Adult abalone generally occupy habitats less hidden than that of juveniles. It is crucial however that the habitat requirements of juvenile abalone are met if recruitment is to be successful. Part of understanding the ecology of the species includes an understanding of the habitat requirements of wild juvenile H. mariae. This understanding will also play a crucial part in providing information that can be used to select suitable conservation areas for the species.

This study investigates habitat preferences of wild juveniles along the Dhofar coast with the aim of quantifying the relationship between substratum structure, urchins and wild juveniles. It was conducted with a number of questions in mind: (1) Are there specific physical substratum limitations in effect in the distribution of wild juvenile abalone? (2) Is the availability of habitat a limiting factor with respect to recruitment, how much habitat is being utilized by juvenile abalone? (3) What is the relationship between wild juvenile abalone and the sea urchin? (4) Are there findings that impact on potential conservation of this species?

\section{Materials and Methods}

\section{Quantitative Wild Juvenile Surveys}

Between March and early April 2012, juvenile specific surveys were conducted in four abalone fishery areas: Mirbat, Sadah, Hadbin and Hassik (Fig.1). Abalone smaller than $\approx 3 \mathrm{~cm}$ (SL) were classified as juvenile. The survey comprised 35 separate $10 \mathrm{X} 1 \mathrm{~m}$ transects, totalling $350 \mathrm{~m}^{2}$, placed randomly in areas considered to be prime abalone fishing areas. Transects were placed both parallel and perpendicular to the beach and did not exceed an average depth of $6 \mathrm{~m}$. In each transect a destructive invasive search was conducted; all boulders, stones and urchins were lifted and searched, cracks and crevices were searched where possible (Rogers-Bennet et al., 2002). In addition to an abalone and urchin count, average depth was recorded in each transect. An estimate was made of the physical substratum in the following categories (de Waal, 2002): (1) Percent area exposed. This is defined as open reef, bedrock or sand, area that does not provide any shelter for juvenile abalone. Exposed reef does not necessarily have to be flat and open; many exposed areas have a high degree of rugosity (Southwest Region Protected Resources Division, 2011; McCormick, 1994) and may be complex in features including outcrops, pockets, and ridges. While not providing under-boulder habitat these areas may provide anchor opportunities for sea urchin species which in turn offer shelter to juvenile abalone. (2) Boulders with diameter $(\varnothing)$ greater than $(>) 50$ $\mathrm{cm}$. (3) Boulders with $\varnothing$ between $(><) 30$ and $50 \mathrm{~cm}$. (4) Boulders with $\varnothing$ less than $(<) 30 \mathrm{~cm}$.

All juvenile abalone and urchins in each transect were counted. For each juvenile the exact position was recorded in the categories described above, in addition to being found under an urchin.

\section{Data Analyses}

Abalone densities and urchin densities were calculated for each transect. Proportional distribution of each habitat category and the proportional utilization of each category, including urchins, by juvenile abalone were calculated (Table 1). The following statistical analyses (using StatistiXL Software) were conducted: (1) Non parametric Kruskal-Wallis Tests were conducted to test for differences in habitat composition between the four areas. (2) Linear regression analyses to test for relationships between number of juveniles found and habitat composition in the categories listed above including depth and number of urchins per transect. (3) Selectivity analyses of juvenile abalone for substratum habitat categories including urchins for shelter:

The selectivity analyses were done using Manley's formula that calculates a resource selection function $\mathrm{w}_{\mathrm{i}}$ (the relative probability of selection for the category i, Formula I) for the different categories of resource available. The selection function attempts to estimate the probability that the next resource used will be of a specific type. It allows a biological interpretation of used and available resource ratios by animals, and has been used to test habitat selectivity by abalone (de Waal, 2002; Manly et al., 2002; Day and Branch, 2002, 2000).

$$
\mathrm{w}_{\mathrm{i}}=\mathrm{u}_{\mathrm{i}} / \mathrm{m}_{\mathrm{i}}
$$

$\mathrm{w}_{\mathrm{i}}$ is the selectivity ratio; $\mathrm{m}_{\mathrm{i}}$ is the number of available units in category $i$ in a sample of available resource units; and $u_{i}$ is the number of units in category $i$ in a sample of used units.

A useful way of presenting selection ratios is to standardize them so that they add up to a total of 1 . This leads to Manly's standardized selection ratio $\mathrm{B}_{\mathrm{i} 1}$ (with used resource units replenished or in this case constant, Formula II).

$$
\mathrm{B}_{\mathrm{i} 1}=\left(\mathrm{u}_{\mathrm{i}} / \mathrm{m}_{\mathrm{i}}\right) / \Sigma\left(\mathrm{u}_{\mathrm{i}} / \mathrm{m}_{\mathrm{i}}\right)
$$


Table 1. General data describing biological and substratum characteristics from each transect. Proportional distribution of habitat categories and proportional distribution of utilization of different habitat categories by juvenile abalone from each fishing area are shown.

\begin{tabular}{|c|c|c|c|c|c|c|c|c|c|c|c|c|c|}
\hline & \multirow{2}{*}{ Site } & \multirow{2}{*}{$\begin{array}{l}\text { Depth } \\
\text { (m) }\end{array}$} & \multirow{2}{*}{$\begin{array}{c}\text { Abalone } \\
\mathrm{m}^{-2}\end{array}$} & \multirow{2}{*}{$\begin{array}{l}\text { Urchins } \\
\mathrm{m}^{-2}\end{array}$} & \multicolumn{5}{|c|}{$\begin{array}{c}\text { Proportional Distribution (\% area) } \\
\text { Habitat Categories }\end{array}$} & \multicolumn{4}{|c|}{$\begin{array}{c}\text { Proportional Distribution }(\%) \\
\text { Abalone Utilizing Habitat Categories }\end{array}$} \\
\hline & & & & & Urchins & $\begin{array}{l}<30 \\
\mathrm{~cm} \varnothing\end{array}$ & $\begin{array}{c}30><50 \\
\mathrm{~cm} \varnothing\end{array}$ & $\begin{array}{l}>50 \\
\mathrm{~cm} \varnothing\end{array}$ & Exposed & Urchins & $\begin{array}{l}<30 \\
\mathrm{~cm} \varnothing\end{array}$ & $\begin{array}{c}30><50 \\
\mathrm{~cm} \varnothing\end{array}$ & $\begin{array}{l}>50 \\
\mathrm{~cm} \varnothing\end{array}$ \\
\hline \multirow[t]{13}{*}{ Mirbat } & 1 & 7 & 0.2 & 1.8 & 1.24 & 10 & 20 & 50 & 18.76 & 0.00 & 50.00 & 50.00 & 0.00 \\
\hline & 2 & 6 & 0.2 & 5.1 & 3.50 & 20 & 40 & 20 & 16.50 & 0.00 & 50.00 & 50.00 & 0.00 \\
\hline & 3 & 5 & 0.3 & 4.3 & 2.95 & 10 & 20 & 30 & 37.05 & 0.00 & 100.00 & 0.00 & 0.00 \\
\hline & 4 & 8 & 0.2 & 0.3 & 0.21 & 10 & 10 & 20. & 59.79 & 0.00 & 0.00 & 100.00 & 0.00 \\
\hline & 5 & 6 & 0.4 & 0.6 & 0.41 & 10 & 10 & 10 & 69.59 & 50.00 & 50.00 & 0.00 & 0.00 \\
\hline & 6 & 9 & 0.3 & 1.2 & 0.82 & 10 & 20 & 10 & 59.18 & 0.00 & 0.00 & 100.00 & 0.00 \\
\hline & 7 & 1 & 0 & 7.2 & 4.95 & 10 & 10 & 20 & 55.05 & 0.00 & 0.00 & 0.00 & 0.00 \\
\hline & 8 & 7 & 0.3 & 0.8 & 0.55 & 0 & 0 & 40 & 59.45 & 100.00 & 0.00 & 0.00 & 0.00 \\
\hline & 9 & 5 & 1.2 & 0.2 & 0.14 & 50 & 50 & 0 & 0.00 & 25.00 & 58.33 & 16.67 & 0.00 \\
\hline & 10 & 3.5 & 1.3 & 20 & 13.74 & 0 & 0 & 10 & 76.26 & 69.23 & 0.00 & 0.00 & 30.77 \\
\hline & 11 & 6 & 1 & 2 & 1.37 & 10 & 20 & 60 & 8.63 & 10.00 & 50.00 & 40.00 & 0.00 \\
\hline & 12 & 5 & 0.3 & 1 & 0.69 & 0 & 0 & 60 & 39.31 & 33.33 & 66.67 & 0.00 & 0.00 \\
\hline & 13 & 3.5 & 1.4 & 5 & 3.43 & 10 & 10 & 55 & 21.57 & 21.43 & 42.86 & 35.71 & 0.00 \\
\hline \multirow[t]{13}{*}{ Sadh } & 1 & 3 & 0.7 & 4.8 & 3.30 & 10 & 10 & 60 & 16.70 & 0.00 & 57.14 & 28.57 & 14.29 \\
\hline & 2 & 0.5 & 0.5 & 6 & 4.12 & 10 & 10 & 70 & 5.88 & 60.00 & 40.00 & 0.00 & 0.00 \\
\hline & 3 & 3 & 0.9 & 6.8 & 4.67 & 10 & 20 & 60 & 5.33 & 11.11 & 11.11 & 22.22 & 55.56 \\
\hline & 4 & 3 & 0.9 & 2.4 & 1.65 & 20 & 40 & 40 & 0.00 & 0.00 & 77.78 & 22.22 & 0.00 \\
\hline & 5 & 3 & 0.7 & 4.8 & 3.30 & 10 & 10 & 80 & 0.00 & 0.00 & 42.86 & 57.14 & 0.00 \\
\hline & 6 & 4.5 & 0.2 & 3.8 & 2.61 & 10 & 10 & 10 & 67.39 & 100.00 & 0.00 & 0.00 & 0.00 \\
\hline & 7 & 6 & 1 & 0 & 0.00 & 40 & 10 & 50 & 0.00 & 0.00 & 90.00 & 10.00 & 0.00 \\
\hline & 8 & 4 & 1 & 3.6 & 2.47 & 10 & 10 & 20 & 57.53 & 20.00 & 70.00 & 10.00 & 0.00 \\
\hline & 9 & 2 & 1.1 & 3.8 & 2.61 & 10 & 20 & 20 & 47.39 & 54.55 & 27.27 & 18.18 & 0.00 \\
\hline & 10 & 2.5 & 1.8 & 13.3 & 9.14 & 0 & 0 & 0 & 90.86 & 100.00 & 0.00 & 0.00 & 0.00 \\
\hline & 11 & 1.5 & 0.1 & 1.8 & 1.24 & 10 & 10 & 50 & 28.76 & 100.00 & 0.00 & 0.00 & 0.00 \\
\hline & 12 & 5 & 0.3 & 1.8 & 1.24 & 0 & 0 & 60 & 38.76 & 33.33 & 66.67 & 0.00 & 0.00 \\
\hline & 13 & 3.5 & 1.4 & 1.5 & 3.43 & 10 & 10 & 55 & 21.57 & 21.43 & 42.86 & 35.71 & 0.00 \\
\hline \multirow[t]{3}{*}{ Hadbin } & 1 & 4 & 2.2 & 1.9 & 1.31 & 30 & 30 & 40 & 0.00 & 9.09 & 54.55 & 36.36 & 0.00 \\
\hline & 2 & 4 & 0.8 & 1.2 & 0.82 & 20 & 30 & 20 & 29.18 & 37.50 & 62.50 & 0.00 & 0.00 \\
\hline & 3 & 2 & 0 & 0.4 & 0.27 & 10 & 10 & 50 & 29.73 & 0.00 & 0.00 & 0.00 & 0.00 \\
\hline \multirow[t]{8}{*}{ Hassik } & 1 & 6 & 0 & 0 & 0.00 & 0 & 0 & 0 & 100.00 & 0.00 & 0.00 & 0.00 & 0.00 \\
\hline & 2 & 3 & 0 & 0 & 0.00 & 0 & 0 & 0 & 100.00 & 0.00 & 0.00 & 0.00 & 0.00 \\
\hline & 3 & 6 & 0.1 & 3 & 2.06 & 0 & 0 & 50 & 47.94 & 100.00 & 0.00 & 0.00 & 0.00 \\
\hline & 4 & 3 & 0 & 0.5 & 0.34 & 10 & 10 & 20 & 59.66 & 0.00 & 0.00 & 0.00 & 0.00 \\
\hline & 5 & 3 & 0.1 & 3.6 & 2.47 & 20 & 35 & 35 & 7.53 & 100.00 & 0.00 & 0.00 & 0.00 \\
\hline & 6 & 3 & 0.7 & 3 & 2.06 & 25 & 30 & 40 & 2.94 & 85.71 & 14.29 & 0.00 & 0.00 \\
\hline & & Average & 0.62 & 3.36 & 2.37 & 11.87 & 14.71 & 34.71 & 36.52 & 32.62 & 32.14 & 18.08 & 2.87 \\
\hline & & SD & 0.56 & 3.97 & 2.72 & 11.12 & 13.11 & 22.62 & 30.12 & 38.29 & 31.40 & 27.07 & 10.78 \\
\hline
\end{tabular}


Table 2. Kruskal-Wallace tests on all categories of habitat description including number of urchins per transect.

\begin{tabular}{lccc}
\hline Transect characteristics (SD) & Df & F & P \\
\hline Average depth $(\mathrm{m})$ & 3 & 4.41 & $0.017^{*}$ \\
Average density $\left(\right.$ abalone $\left.\mathrm{m}^{-2}\right)$ & 3.8 & 3.00 & $0.019^{*}$ \\
Average density $\left(\right.$ urchins $\left.\mathrm{m}^{-2}\right)$ & 1.80 & 3.00 & 0.41 \\
\cline { 1 - 4 } Physical substratum & & & \\
\hline Boulders $<30 \mathrm{~cm} \varnothing$ & 1.10 & 3.00 & 0.35 \\
Boulders $30><50 \mathrm{~cm} \varnothing$ & 0.80 & 3.00 & 0.51 \\
Boulders $>50 \mathrm{~cm} \varnothing$ & 1.50 & 3.00 & 0.23 \\
Exposed area & 0.90 & 3.00 & 0.41 \\
\hline
\end{tabular}

*Significant at $95 \%$ confidence limits.

Non-parametric Friedman tests were conducted on the w (Selectivity ratio) and B values (Standardized ratio) for each area grouped to test for differences between the four fishery areas, and on B values from all the sites for each of the different habitat categories, including urchins, grouped to test for differences in strength of preference for different habitats.

\section{Results}

Depth for all sites combined ranged from $1 \mathrm{~m}$ to a maximum of $9 \mathrm{~m}$ (average $4 \mathrm{~m}, \mathrm{SD} 1.1$ ). The average abalone density was 0.63 abalone $\mathrm{m}^{-2}$ (SD 0.37), and the average urchin density 2.8 urchins $\mathrm{m}^{-2}$ (SD 1.6). The averaged data sets calculated for each separate geographic area were too small to allow constructive testing for significance, however, general differences can be seen in Table 1. There are a number of species of urchin found in the area, including Diadema setosum (Leske, 1778), Echinostrephus molaris (Blainville, 1825), Echinometra mathaei (Blainville, 1825), Toxopneustes pileolus (Lamarck, 1816), and Stomopneustres variolaris (Lamarck, 1816). Juvenile abalone are generally associated with the shorter spine dark urchins like S. variolaris and E. mathaei. Abalone densities were lowest in Hassik, the most easterly of the areas, and highest in Hadbin, the area just west of Hassik. In both areas the number of transects surveyed were limited, 3 in Hadbin and 6 in Hassik (Table 1).

Analyses showed that transects were generally similar in physical substratum structure and appearance, and no significant differences were found between the four areas with respect to the physical attributes described in the categories listed in the methods section above. Depth differences between transects, however, tested significant ( $p=0.017$, Table 2$)$. Abalone densities also tested significantly different ( $p=0.019$, Table 2 ), while urchin densities did not. The utilization of urchins by juvenile abalone ranged between geographic areas from a minimum of $15.5 \%$ to a maximum of $47.6 \%$. The area under urchins (using an average urchin $\varnothing$ of $9.3 \mathrm{~cm} \mathrm{SD}$ 1.3 ) is by far the lowest compared to the area under all other categories of substratum (boulders with varying average $\varnothing$, Table 1).

In all four fishery areas the area comprising small boulders $(<30 \mathrm{~cm} \varnothing)$ made up the smallest proportion of boulder habitat (Table 1). In Mirbat and Hassik the proportion of exposed area was higher than the proportion of area under boulders, and in Sadah and Hadbin exposed area was less than that under boulders. It is important here to note how small the proportion of total area comprises small boulders. In this study this category of substratum is shown to be significantly important to juvenile $H$. mariae. Seventy-six percent of wild juvenile abalone utilise $14 \%$ of the total substrate available, that is the area comprising urchins and area under boulders $<30 \mathrm{~cm} \emptyset$. Ninety-seven percent utilize boulders $<50 \mathrm{~cm} \varnothing$, which is $29 \%$ of the available substratum. In other words, less than $30 \%$ of the total available surveyed habitat comprises substratum that can support juvenile abalone, including the area under urchins which will be variable over time.

Analyses (Pearson Correlations and Anova, Table 3, Fig. 2) showed significant positive relationships exist between juvenile abalone densities and small boulders $(<30$ $\mathrm{cm} \varnothing, p=0.049)$, and juvenile abalone densities and urchin densities $(p=0.031)$. The relationships between juvenile abalone densities and all categories of larger boulder tested insignificant. A negative significant correlation was shown to exist between urchin densities and depth $(p=0.037)$.

Non-parametric Friedman tests showed no significant differences $(p=0.416)$ between the four fishery areas when using either $\mathrm{w}$ or $\mathrm{B}$ as a measure. However, the same tests showed the highly significant $(p=0.004)$ difference values of $\mathrm{B}$ for all categories of habitat when

Table 3. Linear regression analyses (Pearson correlation and Anova) for relationships between abalone and urchin densities and substratum categories.

\begin{tabular}{lcc}
\hline & $\begin{array}{c}\text { Pearson } \\
\mathrm{R}^{2}\end{array}$ & $\begin{array}{c}\text { Anova } \\
\text { Prob. }\end{array}$ \\
\hline $\begin{array}{l}\text { Juvenile abalone no vs. } \\
\text { Boulders }<30 \mathrm{~cm} \varnothing \\
\text { Boulders } 30><50 \mathrm{~cm} \varnothing\end{array}$ & 0.112 & $0.049^{*}$ \\
Boulders $>50 \mathrm{~cm} \varnothing$ & 0.044 & 0.227 \\
Exposed area & 0.003 & 0.275 \\
Urchin density & 0.081 & 0.098 \\
Depth & 0.134 & $0.031^{*}$ \\
Urchin no vs. & 0.027 & 0.348 \\
Boulders $<30 \mathrm{~cm} \varnothing$ & & \\
Boulders $30><50 \mathrm{~cm} \varnothing$ & 0.072 & 0.119 \\
Boulders $>50 \mathrm{~cm} \varnothing$ & 0.030 & 0.316 \\
Exposed area & 0.011 & 0.556 \\
Depth & 0.027 & 0.348 \\
\hline
\end{tabular}



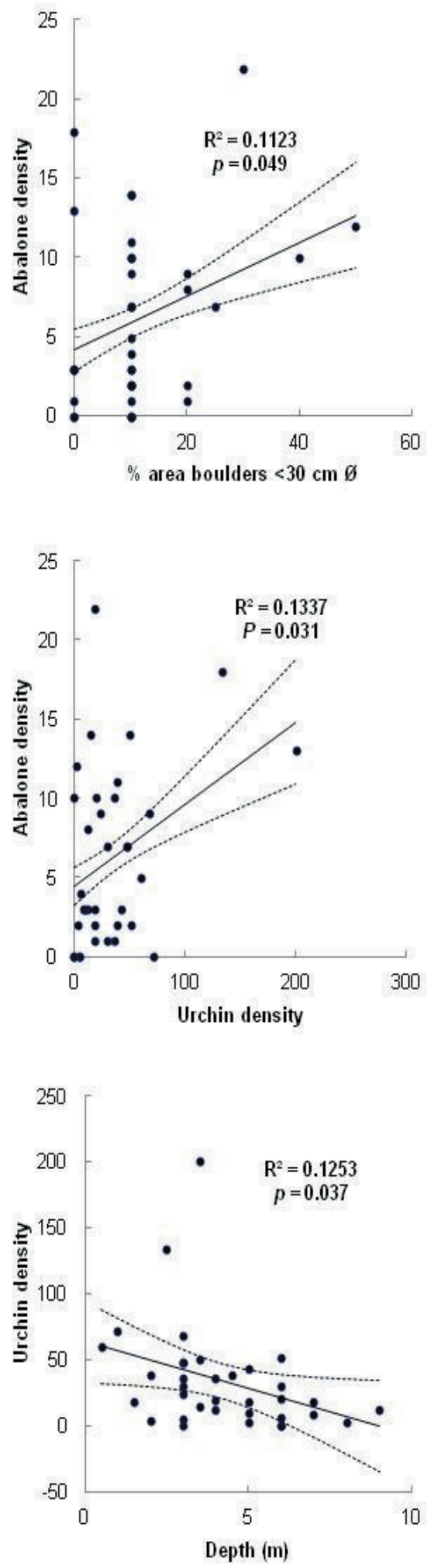

Figure 2. Significant Pearson correlation analyses between abalone and urchin densities, the abundance of small boulders and depth of transects.
Table 4. Standardized B values showing habitat preferences by juvenile abalone (All data is pooled).

\begin{tabular}{lcccc}
\hline Pooled & $\pi$ & 0 & $\mathrm{~W}$ & $\mathrm{~B}$ \\
\hline Urchin area 0.02 & 0.02 & 0.38 & 19.03 & 0.80 \\
$<30 \mathrm{~cm} \varnothing$ & 0.12 & 0.37 & 3.12 & 0.13 \\
$30><50 \mathrm{~cm} \varnothing$ & 0.15 & 0.21 & 1.41 & 0.06 \\
$>50 \mathrm{~cm} \varnothing$ & 0.35 & 0.03 & 0.10 & 0.00 \\
Exposed & 0.36 & 0.00 & 0.00 & 0.00 \\
& & & 23.66 & 1.00 \\
\hline
\end{tabular}

the same categories are grouped from each transect. The standardized B value for urchins selected as shelter by juvenile abalone is almost 6 times higher than for small boulders $(<30 \mathrm{~cm} \varnothing)$. The $\mathrm{B}$ values for the other categories decrease as boulder size increases with a minimum for exposed areas. For boulders $<30 \mathrm{~cm}$ in diameter B is double that for boulders $30><50 \mathrm{~cm}$ diameter (Table 4).

\section{Discussion}

The survey data reflect abalone and urchin densities at a specific time of the year, and therefore must be seen in the context of growth and dispersal, since recruitment, food availability and general environmental conditions vary depending on the season. Analyses were conducted on a specific size range of juveniles. Observations made during other months suggest that juvenile abalone inhabit the same type of habitat throughout this lifecycle phase. Densities, however, will change during the year, and this too has been observed. In this context the abalone densities observed here are relatively low when compared to those from other species, Haliotis rubra (Leach, 1814) juveniles for example average between 1 and $3 \mathrm{~m}^{-2}$ (Roberts et al., 2007; Goodsell et al., 2006). However, this is variable and must be seen in the context of the recent and current status of the abalone stocks in general together with site-specific ecological regimes and habitat characteristics (Roberts et al., 2007). It is not enough to attempt to manage only emergent or adult stocks; in California for example juvenile red abalone abundance was not correlated with local adult red abalone abundance (Rogers-Bennett and Pearse, 2001). In that study it was concluded that fishing for red urchins potentially decreased the microhabitat available for juvenile abalone.

In this study a prime abalone fishing habitat was selected. However, along the entire Dhofar coast suitable habitats for juvenile abalone will be relatively less abundant than in this area. Due to the complex ecological requirements for successful recruitment to take place, 
habitats suitable for recruitment may in fact be more limited than that available for juveniles to live in. The fact that a significant correlation is found between juvenile abalone and small boulders corresponds with findings for abalone species internationally. Juvenile abalone are generally sheltered in the shallows in under-boulder habitats. In New Zealand Haliotis iris (Gmelin, 1791) juveniles are found almost exclusively under boulders from the low water mark to several meters (Roberts et al., 2007). In Canada it was found that juvenile Haliotis Kamtschatkana (Jonas, 1845) require cryptic habitats with some boulders (Lessard and Campbell, 2007). In California Haliotis cracherodii (Leach, 1814) (black abalone) juveniles up to a size of about $20 \mathrm{~mm}$, black abalone are highly cryptic, occurring primarily in under-boulder habitats or in deep narrow crevices (Southwest Region Protected Resources Division, 2011).

It is important to note that these surveys were conducted in areas considered prime adult abalone habitats and does not therefore reflect the entire Dhofar coastline. This limited portion of intertidal and sub tidal habitats is not a safe or stable area when human and natural effects are taken into account. In this habitat juveniles are vulnerable to the movement of boulders, either by natural forces or by humans during abalone fishing or collecting of other marine organisms and the clogging of under-boulder habitats by sand and shale during storms (Roberts et al., 2007; Maliao et al., 2004). It is also this area that is most accessible to people and pollution. For example, trash discarded by fishermen and day visitors in abalone fishery areas along the Dhofar coast is a clear hazard

The positive correlation between juvenile densities and urchin densities combined with the strong selectivity index $\mathrm{B}$ found in this study correspond with a number of international findings. In North America, field studies have shown a strong correlation between juvenile abalone and sea urchins (Rogers-Bennett and Pearse, 2001). In South Africa the same has been found with the species Haliotis midae (Linnaeus, 1758) [Day and Branch, 2002, 2000; Tarr et al., 1996 with similar results in Japanese species (Kojima, 1981)]. It is thought that small abalone are protected by the extended spines of the urchin (Goodsell et al., 2006). In 1997 along the Californian coast between 30 and $45 \%$ of the juvenile Haliotis rufescens (Swainson, 1822) found in specific study sites in marine protected areas were located under the spine canopy of red urchins with the remainder in other microhabitats (Rogers-Bennett and Pearse, 2001). In Canada survey sites showed $7 \%$ of H. Kamtschatkana $<45 \mathrm{~mm}$ SL were found under urchins and a positive correlation was found between abalone numbers and sea urchins (Tomasckik and Holmes, 2003). The same authors found a negative correlation between urchin densities and abalone size, indicating that urchins may have a beneficial role in survival of smaller abalone. Urchins play a significant role in supporting a large proportion $(\approx 31 \%)$ of the wild juvenile abalone population in the fishery areas of the Dhofar coast. While this role is significant it is not vital to juveniles because a larger proportion of juvenile abalone occupy under-boulder habitats.

\section{Conclusions}

It is important to note that the proportion of total habitat that is preferred by more than $97 \%$ of juvenile abalone found, including urchins and boulders $<50 \mathrm{~cm} \varnothing$, comprises $29 \%$ of the substratum surveyed. The proportion of total habitat that will support recruitment requires ecological factors not measured in this study, one being the presence of crustose coralline algae. In effect this additional requirement might make total habitat available for recruitment even less than this. While the role that urchins play on wild juvenile $H$. mariae has not proved vital it is highly significant. However, inferences cannot be made from this data about the relationship between urchins and the recruitment of $H$. mariae. This must be investigated in future studies.

Studies in California and the Philippines have shown that marine protected areas result in an increase in juvenile abalone densities (Maliao et al., 2004; Rogers-Bennett and Pearse, 2001). This study shows that while juvenile densities are low they are not currently limited by the availability of suitable habitat. However, conservation of this species requires managing the entire lifecycle of the species which includes the physical substratum required. It is crucial to identify and conserve those microhabitats that support recruitment of $H$. mariae; shallow intertidal areas easily accessible and most prone to human activities. The distribution and abundance of these areas should be among the criteria used in selecting protected conservation areas.

\section{Acknowledgements}

This study was financed by the Oman Agricultural and Fisheries Development Fund, Sultanate of Oman. We appreciate the support given by the Fisheries Research Centre-Salalah, Ministry of Agriculture and Fisheries Wealth, and the Directorate General of Fisheries in Dhofar.

\section{References}

Al-Gheilani, H.M. 2009. Final Report: Blooms of Cochlodinium Polykroides along the coast of Oman in 2008-2009 and their effects. Internal Report: Marine and Oceanography Section, Marine Science and Fisheries Center, Ministry of Fisheries Wealth.

Al-Hafidh, A.S. 2006. Assessment and management of abalone Haliotis mariae, (1828 Wood) fishery in the Omani water. University of Hull. Hull International Fisheries Institute. Unpublished Ph.D. Thesis. U.K. 137pp.

Al-Rashdi, K.M. and T. Iwao. 2008. Abalone, Haliotis mariae (Wood, 1828), Hatchery and seed production trials in Oman. Sultan Qaboos University Agriculture and Marine Sciences - A Research Journal 13:53-63.

Andrew, N.L. and A.J. Underwood. 1992. Associations and abundance of sea urchins and abalone on shallow subtidal reefs in southern New South Wales. 
Australian Journal of Marine and Freshwater Research 43:1547-1559.

Day, E. and G.M. Branch. 2000. Evidence for a positive relationship between juveniles abalone $H$. midae and the sea urchin Parechinus angulosus in the SouthWestern Cape, South Africa. South African Journal Marine Science 22:145-156.

Day, E. and G.M. Branch. 2002. Effects of urchins (Parechinus angulosus) on juveniles and recruits of abalone (Haliotis midae). Ecological Monographs 72: 133-149.

de Waal, S.W.P. 2002. Factors influencing the ranching of the abalone species (Haliotis midae) along the Namaqualand coast of South Africa. University of Cape Town. South Africa. Unpublished Ph.D. Thesis. 240pp.

de Waal, S.W.P. 2005. Boulders or urchins? Selecting seeding sites for juvenile Haliotis midae along the Namaqualand coast of South Africa. African Journal of Marine Science 27:501-504.

Dixon, C.D., R.W. Day, S.M.H. Huchette, and S.A. Shepherd. 2006. Successful seeding of hatcheryproduced juvenile Greenlip abalone to restore wild stocks. Fisheries Research 78:179-185.

Fishery Statistics Book, 2012. Fisheries Statistics and Information Department. General Directorate of Fisheries Research. Ministry of Agriculture and Fisheries Wealth, Sultanate of Oman.

Goodsell, P.J., C,A.J. Underwood, M.G. Chapman, and M.P. Heasman. 2006. Seeding small numbers of cultured black-lip abalone (Haliotis rubra Leach) to match natural densities of wild populations. Marine and Freshwater Research 57:747-756.

Heasman, M.P., W. Liu, P.J. Goodsell, D.A. Hurwood and G.L. Allan. 2007. Development and delivery of technology for production, enhancement and aquaculture of blacklip abalone (Haliotis rubra) in New South Wales. FRDC Project No. 2001/033 NSW Department of Primary Industries-Fisheries Final Report Series No. 95 ISSN 1449-9967.

Kojima, H. 1981. Mortality of young Japanese black abalone Haliotis discus discus after transplantation. Bulletin of the Japanese Society of Scientific Fisheries 47:151-159.

Lessard, J. and A. Campbell. 2007. Describing Northern abalone, Haliotis Kamtschatkana, Habitat: focusing rebuilding efforts in British Columbia, Canada. Journal of Shellfish Research 26:677-686.
Maliao, R.J., E.L. Webb, and K.R. Jensen. 2004. A survey of stock of the donkey's ear abalone, Haliotis asinina L. in the Sagay Marine Reserve, Philippines: evaluating the effectiveness of marine protected area enforcement. Fisheries Research 66:343-353.

Manly, B.F.J., L.L. McDonald, D.L. Thomas, T.L. McDonald, and W.P. Erickson. 2002. Resource Selection by Animals. Statistical Design and Analysis for Field Studies (2nd Edition). Kluwer Academic Publishers, Boston, MA, USA, 240pp.

McCormick, M.I. 1994. Comparison of field methods for measuring surface topography and their associations with a tropical reef fish assemblage. Marine Ecological Progress Series 112:87-96.

Roberts, R.D., E.F. Keys, G. Prendeville, and C.A. Pilditch. 2007. Viability of abalone (Haliotis Iris) stock enhancement by release of hatchery-reared seed in Marlborough, New Zealand. Journal of Shellfish Research 26:697-703.

Rogers-Bennet, L., P.L. Haaker, T.O. Huff, and P.K. Dayton. 2002. Abalone baselines in California. Estimating baseline abundances of abalone in California for restoration. California Cooperative Oceanic Fisheries Investigations 43:97-111.

Rogers-Bennett L. and J.S. Pearse. 2001. Indirect benefits of marine protected areas for juvenile abalone. Conservation Biology 15:642-647.

Sanders, M.J. 1982. Preliminary stock assessment for the abalone taken off the south east coast of Oman. Fisheries Development in the Gulf FI; DP/RAB/80/ 015/3. FAO. Rome. 47pp.

Southwest Region Protected Resources Division, 2011. Final Designation of Critical Habitat for Black Abalone. Final Biological Report. National Marine Fisheries Service. 501 West Ocean Blvd., Suite 4200 Long Beach, California 90802. 59pp.

Tarr, R.J.Q., P.V.G. Williams, and A.J. Mackenzie. 1996. Abalone, sea urchins and rock lobster: a possible ecological shift that may affect traditional fisheries. South African Journal of Marine Science 17:319-323.

Tomascik, T. and H. Holmes. 2003. Distribution and abundance of Haliotis kamatschatkana in relation to habitat, competitors and predators in the Broken Group Islands, Pacific Rim National Park Reserve of Canada. Journal of Shellfish Research 22:831-838.

Received: October 9, 2012

Accepted: January 16, 2013 